\title{
The reception of Greek lyric poetry in the ancient world: transmission, canonization, and paratext
}

Book or Report Section

Accepted Version

Currie, B. and Rutherford, I. (2020) The reception of Greek lyric poetry in the ancient world: transmission, canonization, and paratext. In: The Reception of Greek Lyric Poetry in the Ancient World: Transmission, Canonization and Paratext.

Studies in Archaic and Classical Greek Song (5). Brill, pp. 136, Mnemosyne, Supplements, Vol. 430. ISBN

9789004414518 doi:

https://doi.org/10.1163/9789004414525_002 Available at https://centaur.reading.ac.uk/88343/

It is advisable to refer to the publisher's version if you intend to cite from the work. See Guidance on citing.

To link to this article DOI: http://dx.doi.org/10.1163/9789004414525_002

Publisher: Brill

All outputs in CentAUR are protected by Intellectual Property Rights law, including copyright law. Copyright and IPR is retained by the creators or other copyright holders. Terms and conditions for use of this material are defined in the End User Agreement. 


\section{www.reading.ac.uk/centaur}

\section{CentAUR}

Central Archive at the University of Reading

Reading's research outputs online 
CHAPTER 1

\title{
The Reception of Greek Lyric Poetry in the Ancient World: Transmission, Canonization, and Paratext
}

\author{
Bruno Currie and Ian Rutherford
}

$1 \quad$ Introduction

To approach a fuller understanding of any work of ancient Greek literature we need to pay attention to reception, not only its immediate reception by contemporary and near-contemporary audiences (insofar as there is any direct evidence for that), but also its longer-term reception in later Greek and Roman culture. There are two main parts to this inquiry. One is transmission: the process by which literary works were passed on to later generations and made available to listeners and readers. The other is the broader impact on GrecoRoman intellectual culture: the ways in which the texts are used by writers, critics, or visual artists. Their views are bound to be shaped to some extent by the tastes of the particular historical period in which they lived, but they may also draw on established interpretative traditions, which in some cases go back to the period when the works were first composed. These two issues of tradition and broader impact are closely linked, both because a citation or allusion may provide at least indirect evidence for transmission, and because the attitudes of later writers and intellectuals can help to explain why it was believed to be necessary to transmit the texts in the first place.

For the study of Greek song - melic, iambic, and elegiac poetry-of the seventh to fifth centuries BCE, understanding ancient reception is particularly important. In this case the process of transmission had an exceptionally transformative effect, seeing the conversion of musical performances into written texts lacking any form of musical (or choreographical) notation. With the creation of a literary "canon", the Greek lyric tradition underwent what Jan Assmann has called "excarnation": a process of becoming disembedded from its original context. ${ }^{1}$ The creation of a canon in this context entails not only the creation of canonical poets (an exclusive list of specially favoured authors), but also of canonical texts (texts fixed in their precise wording and maybe even in

1 Assmann (2006) 65-70; he credits Almeida Assmann with the invention of the term. 
their colometry); both aspects are relevant to this volume. ${ }^{2}$ A second reason for the importance of reception to early Greek song specifically is that comparatively few texts from these genres survive complete, and much of what comes down to us takes the form of short excerpts ("fragments") scattered in the texts of other writers. Many of these are presumably faithful citations (direct or indirect) of some version of a text that was in circulation, but others could be distorted or even invented. Thus, it is crucial to be aware of the agendas of the embedding authors. Finally, the surviving texts of lyric poetry, even the nearly complete, are often not entirely comprehensible in themselves; many of them require that we grasp topical allusions or know something about the circumstances of performance, and some, such as Pindar's Epinicia, contain language that is, at least prima facie, obscure. For all these reasons, lyric poetry in antiquity was bound up with commentary and we for our part are more than usually dependent on the opinions of ancient writers and scholars who, whatever their limitations and idiosyncrasies, at least had access to much more primary material than we do. ${ }^{3}$

The aim of the chapters collected in the present volume is to examine aspects of the reception and transmission of ancient Greek song in the ancient world. It had its origins in an international conference, 'The Reception of Greek Lyric Poetry 6оо вCE-40о CE: Transmission, Canonization, and Paratext' held at the University of Reading in September 2013, under the auspices of the Network for the Study of Archaic and Classical Greek Song. Neither the volume nor this introduction claims to give comprehensive coverage of the subject, and although all of the chapters here are self-contained, it may be helpful to attempt a sort of overview of the subject they address in their different ways.

A useful way of approaching the ancient reception of Greek lyric chronologically is to break it down into a number of stages, none of them entirely clear, but some clearer than others. Probably the best understood is the Hellenistic period, when scholars in Alexandria are believed to have produced editions of the texts (Stage 4 below). Before that, we find traces of Peripatetic interest in the fourth century в СЕ (Stage 3) and signs of an early canon forming in Athens (Stage 2). The hardest to make out is the period before the fifth century (Stage 1), with which our chronological survey, necessarily very partial and selective, begins.

2 On the interconnection of these two aspects of "canonization", see Lardinois' contribution to this volume, p. 49.

3 Hutchinson (2007) 36. 


\subsection{Stage 1: The Seventh and Sixth Centuries BCE}

Most of the melic, elegiac and iambic poets who later became canonical date from the seventh and sixth centuries BCE, and they practised their art in different parts of Greece: Sparta, Ionia, and the West. How did their songs come through to the fifth century всЕ? While a complete answer to this question is beyond our grasp, we can sketch out three aspects that may have played a role.

The first could be described as selection and Panhellenization. Although there must have been hundreds of singers in Greece in the seventh and sixth centuries BCE, only a small number achieved the status of classics. Many of them must have been forgotten quickly or were remembered for a single composition, such as the one-hit-wonder Tynnichus (Plato, Ion 534d). The successful ones must have owed much of their success to their ability to reach beyond their local communities, and to secure recognition at the Panhellenic level. In some cases Panhellenic recognition may have come after the poet's death, but in others it may have been achieved in his lifetime through travelling and performing at festivals or by constructing poems in such a way as to appeal to a general audience. ${ }^{4}$ The poet's Panhellenic ambition is sometimes made explicit in the poetic texts (e.g. Pindar, Olympian 1.115b-116).

The second aspect is the role played by oral and written transmission. Some see transmission as largely oral right down to the fifth century BCE, and possibly later, with writing playing only a supporting role. Gregory Nagy, ${ }^{5}$ for example, has seen the transmission of the poems in terms of generations of singers who, by performing the songs associated with a given poet, take on his or her persona. Thus, what is passed down is not the song but the performance tradition and the associated persona, with writing playing at most a secondary role. Others see even the earliest melic poems as being written down from the start, a position that need not presuppose the existence of a significant reading public, as the main purpose of written texts may have been to ensure the continued performance of lyric compositions in a form faithful to the original. ${ }^{6}$ This debate replicates one concerning early Greek epic, and equally eludes consensus. ${ }^{7}$ Intermediate positions are also possible, such that writing was introduced in, say, the mid-sixth century BCE, an early sign of this potentially being Theognis' "Seal" elegy, if that implies a literal seal on a written document (which

4 For poets travelling and performing at festivals, see Hunter and Rutherford (2009). For poems as constructed so as to appeal to a wider audience, see Carey (2011) 442-445, but see also Currie (2017) 202-208.

5 Nagy (1990) 36-82.

6 Stehle (1997) 262-318, on Sappho.

7 Nagy (1990) 38-82, (1996) 29-63; Fowler (2004). 
is uncertain). ${ }^{8}$ Possibly there was a correlation between the increasing Panhellenization of song and the need for writing to stabilize the text when performed beyond the local communities. But even that is unclear; frequent performance even within local communities could give rise to a desire to standardize the text that was to be performed (as with Lycurgus' establishment of "official" texts of the three great tragedians in fourth-century BCE Athens).

The third aspect is control of the tradition. Was it simply left to itself or did some parties have a special role in shaping it? One interested party might be the lyric poets themselves, who could have helped to shape the emerging tradition. We know at least that poets cite their predecessors: Solon cites Mimnermus, Simonides cites Stesichorus, and Pindar refers to Archilochus and to the (to us) uncanonical Sacadas of Argos and Xenocritus of Locri. In other words, the question of how poets themselves viewed the lyric tradition arises already for the archaic and early classical periods, as well as for the later fifth century. ${ }^{9}$ This all pertains to the creation of a "canon" of elite poets. The other aspect of the control of the tradition is the creation of "canonical", or authorised, fixed, texts. It is natural to think of the poets themselves as taking an interest in the textual preservation of their own work (consider Theognis' "Seal" again). While there is no sign of any central archive, the home cities of poets might also patriotically have played a part by preserving the texts of their poets. ${ }^{10}$ Another factor shaping the early textual tradition could have been the tastes of the participants in the institution of the symposium. Vases depict Anacreon and Sappho at the symposium. ${ }^{11}$ Already at a relatively early date, lyric anthologies may have been made to cater to sympotic reperformance. ${ }^{12}$ Performance of Stesichorus at the symposium may be implied by the proverb, 'the three of Stesichorus.' ${ }^{13}$

Whether oral or written or possibly an interactive combination of the two, the nature of early transmission is likely to have resulted in a high degree of instability in the texts transmitted. (The classic illustration of this is the variation found between the text of a song of Alcaeus as preserved for us on papyrus from a Hellenistic book-edition of the poet, fr. 249.6-9, and as transmitted as an Attic drinking-song or skolion, $891 P M G .^{14}$ ) From the point of view of the

\footnotetext{
8 Cerri (1991); Bakker (2017).

9 This question is addressed in the contributions to this volume of Calame, pp. 114-119 (focussing on Aristophanes' citatory practice with the melic poets), and Fearn, pp. 210220 (considering Timotheus' relationship with Simonides, Pindar, and Bacchylides).

10 See Lardinois' contribution to this volume, pp. 43-44.

11 Yatromanolakis (1997). Compare Nagy's contribution to this volume, p. 103.

12 See the contributions to this volume of Bartol, pp. 139-140, and Caciagli, p. 327.

13 See Capra's contribution to this volume, p. 251.

14 See Lardinois' contribution to this volume, pp. 6o-62.
} 
modern editor the question arises whether it is possible or desirable to seek to establish a single reading. ${ }^{15}$ The nature of the early transmission would also have provided scope for pseudepigraphy of various sorts. In Athens in the later fifth century when the canon was coming into being there could well have been a tendency to ascribe a wide variety of cult songs emanating from Sparta to Alcman, for example.

\subsection{Stage 2: Fifth-Century Athens}

The next phase was Athens in the later fifth century BCE, which was, as far as we can tell, the principal centre of Greek musical culture at this time. None of the melic poets who later became canonical was an Athenian, though Simonides and Anacreon ${ }^{16}$ were resident there under the tyrant Hipparchus, ${ }^{17}$ and Pindar and Bacchylides composed dithyrambs for the Athenian Dionysia. Lyric poetry is a major intertext for tragedy. ${ }^{18}$ Comedy, too, shows an awareness of most of the poets and genres who later came to make up the melic canon. ${ }^{19}$ Aristophanes reveals a notable leaning to the older, deceased, lyric poets in preference to contemporary practitioners of the New Music. ${ }^{20}$ Several comedies about or featuring Sappho were produced from the fifth century into the fourth century вСЕ. ${ }^{21}$ Herodotus, active in the third quarter of the fifth century and plainly envisaging an Athenian readership, though not exclusively, refers to events in the lives of three melic poets, Alcaeus, Sappho, ${ }^{22}$ and Simonides, as well as the non-melic "lyric" poets Archilochus and Solon. The dialogues of Plato, set in the Athens of the later fifth century, feature frequent quotations and discussions of melic poets such as Simonides, Pindar, and Stesichorus. ${ }^{23}$

Plato's dialogues, which look back to the late fifth century, confirm the impression that Athenian intellectuals were familiar with a wide range of Greek song and engaged keenly in debates about its merits. Stesichorus' Palinode

15 This question is a preoccupation of the contributions to this volume of Lardinois and van Hilten-Rutten.

16 For Anacreon, see now Bing (2014).

17 See Nagy's contribution to this volume, p. 101.

18 Swift (2011). For the reception of choral lyric in drama, an important guide is Herington (1985); in tragedy, Bagordo (2003); in comedy, Kugelmeier (1996). Excellent overviews are Hutchinson (2001) 427-439 and Stehle (2004).

19 See Calame's contribution to this volume.

20 See Hadjimichael's contribution to this volume, p. 165.

21 For Sappho on the stage, see Parker (1993) 309-310n2; Yatromanolakis (2007) 70-71; Olson (2007) 303-304; Schlesier's contribution to this volume, pp. 353, 365-366.

22 See Kazanskaya's contribution to this volume.

23 See Capra's contribution to this volume. Plato also cites the non-canonical lyric poets Tynnichus of Chalcis $($ Ion $534 \mathrm{~d}=707$ PMG) and Cydias $($ Charm. $155 \mathrm{~d}=714 P M G)$. 
plays a central role in the Phaedrus,$^{24}$ and the protracted discussion of the Scopas ode of Simonides in the Protagoras furnishes the first recorded case of textual exegesis. ${ }^{25}$ Simonides also plays a major part in Xenophon's Hiero where he is imagined as engaging in dialogue with the Sicilian tyrant. The existence of a treatise On Theognis ascribed to Xenophon may be a sign of the popularity of Theognis among Athenians with oligarchic sympathies in this period. ${ }^{26}$

It is unclear to what extent there was a reading public for poetry at this time. ${ }^{27}$ By contrast, various mechanisms are conceivable by which songs could be experienced in performance. It has been suggested that there was a permanent institutional venue in the Panathenaia festival. ${ }^{28}$ Another venue would have been the symposium. Sympotic anthologies are thought to be have been created in the sixth and fifth centuries BCE. ${ }^{29}$ Transmission in such anthologies would constitute a way in which texts of the archaic lyric poets (e.g. Alcaeus and Sappho) might reach later authors (such as Athenaeus) independently of Alexandrian editorial activity.

Lyric was still a living tradition at this time, but there is a sense of a "canon" emerging, the latest of the soon-to-be canonical melic poets (Simonides, Bacchylides, Pindar) having died around the middle of the fifth century. ${ }^{30}$

Around this time we hear of literary critical works, mainly focussing on Homer, for instance, by Theagenes of Rhegium. No treatises about lyric poetry are known from this period, though lyric poetry may have been discussed in the context of mousike by early musical writers such as Lasos of Hermione and Damon. Theoretical statements about lyric poetry were also made in passing by poets. ${ }^{31}$ Our principal resource, though not a straightforward one, for reconstructing Athenian attitudes are the comedians, who suggest that by their time some, at least, of the lyric poets were seen as conservative, ${ }^{32}$ presumably in contrast to the musical tastes of the later fifth century, which leaned towards

\footnotetext{
24 See Capra's contribution to this volume.

25 Most (1994).

26 Stobaeus, Florilegium 88.14. See Lane Fox (2000). For the use of the Theognidean corpus at Athens in this period, see Colesanti (2011) 329-330; Bartol's contribution to this volume, pp. 139, 142.

27 Compare Wright (2012) 146-147.

28 See Nagy's contribution to this volume.

29 See n. 12 above.

30 For the formation of the canon in Athens in this period, see Nicolai (2014) 35-37, (2006).

31 For poets' statements, see Rossi (1971) 75-76; Ford (1995) 10-13. Critias' use of the terms elegeion and iambeion is discussed in Bartol's contribution to this volume, pp. 136-137.

32 Cf. Ar. Clouds 1357-1358 on Simonides; Eupolis fr. 148 and 395 PCG.
} 
the New Music and avant-garde figures such as Melanippides of Melos and Timotheus of Miletus. ${ }^{33}$ The old order was changing.

The fifth-century sophists are likely to have played a part in the development of literary critical discourse, even if they may not, for the most part, have produced literary critical treatises. ${ }^{34}$ (We may note, however, Theagenes and Protagoras' pronouncements on Homer, and 'Protagoras" on Simonides in Plato's Protagoras.) It is unclear to what extent sophistic ideas are reflected in Old Comedy. ${ }^{35}$ It is possible that the sophistic distinction between the instructional and recreational aspects of literary influenced the fifth-century transmission of elegy in an anthologised form. ${ }^{36}$

\subsection{Stage 3: The Fourth Century всE}

The first known texts of melic poets are from the fourth century: the papyrus of Timotheus' Persai from Abusir in Egypt (possibly produced within the lifetime of Timotheus himself) and epigraphic texts such as the Paean to Dionysus by Philodamus of Scarpheia from Delphi. ${ }^{37}$ It is striking that the two earliest preserved texts are of non-canonical poets, and both can be seen as innovative literary experiments. It is not until the beginning of the third century BCE that we encounter the earliest preserved text of any canonical lyric poet: the "Cologne papyrus" of Sappho. ${ }^{38}$

There is no evidence of Aristotle and the Peripatetic philosophers producing texts of the poets. ${ }^{39}$ Aristotle had little to say about lyric in his Poetics, ${ }^{40}$ though he makes extensive use of Solon's poetry as a historical source in his Constitution of Athens. ${ }^{41}$ Chamaeleon and other Peripatetics, however, show an interest at least in the biographies of lyric poets.

\section{$1.4 \quad$ Stage 4: The Hellenistic Period}

Scholars in Hellenistic Alexandria are believed to have produced standard editions of the poets, together with commentaries. Most work was done by Aris-

\footnotetext{
33 On Timotheus, see Fearn's contribution to this volume.

34 For Gorgias as an important influence on Timotheus' Persae, see Fearn's contribution to this volume, pp. 226-234.

35 See Dover (1993) 31-32; Wright (2012) 106-107.

36 See Bartol's contribution to this volume, pp. 140-141.

37 For Timotheus, see van Minnen (1997).

38 See Gronewald and Daniel (2004) 1.

39 See Hadjimichael's contribution to this volume, pp. 174-175; Hadjimichael (2019).

40 See the contributions to this volume of Hadjimichael, pp. 177-178 and Bouchard, pp. 184189 .

41 See Stehle (2006), and Bouchard's contribution to this volume, p. 189.
} 
tophanes of Byzantium (late third century ВСЕ) and Aristarchus (early second century BCE), but Zenodotus and Callimachus (early third century ВСЕ) had anticipated them to some extent: Zenodotus corrected the text of Pindar, and Callimachus had views on the genres of lyric poems. ${ }^{42}$ All of them were probably using texts of the poets that had been collected for the use of the Library of Alexandria, perhaps drawing these from archives in local communities such as Sparta for Alcman and South Italy or Sicily for Stesichorus. ${ }^{43}$

The following are some of the key aspects of Hellenistic editorial practice.

(i) Genre: in the cases of many of the poets, poems were henceforth grouped by category, arranged in a scroll comprising poems judged to belong to the same genre (paean, dithyramb, and so on). This practice, which in some cases knowingly involved messy compromises for practical convenience (e.g. Pindar, Nemeans 9-11), may have created the impression that genres were more clear-cut than they were. ${ }^{44}$ The idea that lyric poems fell into distinct genres was not new (it is clearly formulated in Plato's Laws, for example, and implied in Pindar, fr. 128c); but in the preceding centuries, instead of a rigid system of genres, we should probably think of fluid conventions and a degree of evolution, as in the case of elegy. ${ }^{45}$

(ii) Music: Hellenistic scholars followed fourth-century practice (as seen in the Timotheus papyrus) in not attempting to annotate the music of any song of the classical lyric poets. ${ }^{46}$ It is not clear whether they assumed general knowledge of the music, or whether they just thought it unimportant. They did, however, arrange the texts in metrical cola: Aristophanes of Byzantium is usually said to have established the practice, ${ }^{47}$ although an early Hellenistic papyrus of Sappho that has the text arranged in cola predates Aristophanes, and the Lille Papyrus of Stesichorus may be earlier as well. ${ }^{48}$ It is unknown whether the Hellenistic colometry reflects

42 Pfeiffer (1968) 117-118; for Pindar in general, Dickey (2007) 38-40. For Callimachus and genre, a vivid illustration is P.Oxy. 2368; cf. also schol. Pind. Pyth. 2 inscr.

43 Alcman: Carey (2011); Stesichorus: Cassio (1997).

44 Harvey (1955); Rossi (1971) discusses written and unwritten laws of genres in general; see also Calame (1974).

45 On elegy, see Bartol's contribution to this volume. For iambos, see Rotstein (2010). The apparent evolution of dithyramb from Dionysiac hymn to narrative song, for which see Käppel (2000), is another famous case.

46 Musical notation itself goes back at least as far as the fourth century BCE, since Aristoxenus of Tarentum was moved to express disapproval of it: Harm. 2.39-41, but its applications were limited. Compare Hagel (2010) 1, 3 .

47 Pfeiffer (1968) 187; Montana (2015) 120-121.

48 Nünlist (2015) 735; contrast West (1978) 3-4. 
the musical practice of the original poets. A century ago, Wilamowitz was sure that there was no connection, but today many scholars are prepared to believe that there was at least an element of continuity. ${ }^{49}$ In any case the experience of Hellenistic and Roman readers who knew the songs as music-free, colometrized columns of text was clearly radically different from that of audiences who heard them performed centuries before. The experience of reading the poems in the standard book editions may also be contrasted with that gleaned from some Hellenistic and Roman texts of non-canonical songs preserved on papyrus or stone that did not arrange the text in (the same) metrical cola, and did sometimes include musical notation. ${ }^{50}$

(iii) The "canon": there is reason to believe that Hellenistic scholars also produced an official list of nine melic poets judged to belong to the first class. ${ }^{51}$ They may have produced a shorter list of preferred iambic poets as well. ${ }^{2}$ For the melic poets, none later than Bacchylides was included, entailing the omission of Timotheus and Melanippides (the greatest of the dithyrambic poets, according to Xenophon, Memorabilia 1.4.3). We may contrast the Alexandrian list of epic poets, which accommodated one poet (Antimachus of Colophon) who lived around 400 B CE (Quintilian 10.1.53-54). The preference for the great poets of the period 70o45 О ВСЕ implied in this section seems to reflect the judgements implied in Aristophanes' comedies two centuries earlier (see above, under Stage 2). In subsequent centuries the lyric poets are, for the most part, those nine, though there are exceptions, such as Timotheus, who continues to be regarded as a classic for some time (he was reperformed in Arcadia according to Polybius, 20.8-9), ${ }^{53}$ although there are no signs of Hellenistic editions of his works. Another problematic case is Corinna of Tanagra, now generally believed to have lived in the fifth century ВСЕ, whose songs may have been preserved in a local Boeotian archive, if they did not make it to Alexandria. ${ }^{54}$ We may note also

49 Wilamowitz (1921) 83. See, differently, Montana (2015) 62, $121 n 278$.

50 D'Alessio (2017) 242 (colometry) and 249-25o (musical notation).

51 Pfeiffer (1968) 207; Nicolai (1992) 251-265 and 275-296. Wilamowitz was mistaken to think nine represented all that survived: D'Alessio (2017) 233.

$5^{2} \quad$ For the canon of iambographers see Rotstein (2010) 28n11, (2016). For a canon of archaic and classical elegiac poets there is less to go on, perhaps because they were superseded by the Hellenistic ones (Quintilian 10.1.59). See Kroehnert (1897) 30.

53 On Polybius' citation of Timotheus, see Prauscello (2009).

54 See Larson (2002); a Hellenistic date for Corinna had previously been argued by West (1970). For Corinna as the "tenth", see Nagy's contribution to this volume, p. 11o. See also D'Alessio (2017) 232-233. 
Thaletas of Gortyn, an obscure early poet, whose songs were apparently performed by ambassadors from Mylasa visiting Crete in the second century ВСE; assuming these were genuine poems and not fakes, the question arises how these got to Mylasa: were they perhaps preserved in Gortyn?55 This reminds us that the Alexandrians did not necessarily—at this stage—have a monopoly on the lyric tradition.

We know something, then, about Hellenistic scholarship; but we need to remember how much we do not know. For one thing, we cannot be certain that there were not alternative editions of some poets in circulation. ${ }^{56}$ And we have very little information about how Hellenistic scholars dealt with elegiac and iambic poetry. It is striking that the only book of classical song that comes down to us in manuscript tradition apart from Pindar, Theognis' elegies, is a compilation from several early collections of poems, some likely to be by Theognis, some obviously not, and it is unclear what role, if any, Alexandrian scholars played in its creation. ${ }^{57}$ Another mode of transmission was the poetic anthology, attested from about 300 BCE. ${ }^{58}$ Equally, some poetry may have been transmitted in a way that bypassed the Hellenistic editors; for example, the famous Hymn to Asclepius from Erythrae, which survives in three copies, two from the fourth century BCE and one from Roman Egypt. It should be remembered too that in some cases even the Hellenistic scholars were uncertain of the authorship of particular poems. ${ }^{59}$

In the Hellenistic period we find lyric, elegiac, and iambic poets referenced and imitated by poets of the time, such as Callimachus, who himself wrote lyric poems and iambics. ${ }^{60}$ Anacreon's simple symposiastic verse lent itself particularly well to imitation and so-called "Anacreontea" seem to have been composed from the Hellenistic period right through to the Byzantine period. ${ }^{61}$

55 Chaniotis (1988).

56 Compare Lardinois' contribution to this volume, pp. 55-57 (after E. Bowie), on two editions of Theognis from the fourth century BCE.

57 See the contributions to this volume of Bartol, p. 139, and Caciagli, p. 326, as well as West (1974) 40-59; Bowie (1997).

$5^{8}$ Pordomingo Pardo (2013), e.g. the songs of Elephantine, Pordomingo Pardo no. $21=917$ $P M G$.

59 We find them uncertain about the hymn to Athene cited by Aristophanes (735 PMG: Lamprocles? Stesichorus? Phrynichus?). Compare the judgment of Eratosthenes, discussed by Pfeiffer (1968) 162. Similar uncertainty is shown in P.Oxy. 2737.i.22-26 $=S L G$ 2, which discusses the genre of a line cited by Aristophanes: was it by Terpander, Ion, or Alcman?

6o See now Acosta-Hughes (2010).

61 West (1984) p. vxii; Rosenmeyer (1992). 
Meanwhile, some of the great poets were the subject of veneration, most prominently Archilochus on Paros, a cult of whom was founded by one Mnesiepes in the third century все. ${ }^{62}$ One of Callimachus' Aitia is devoted to the ruined tomb of Simonides of Ceos in Acragas. ${ }^{63}$ Stesichorus had a celebrated octagonal tomb at Catania in Sicily, and Ibycus probably had one at Rhegium. ${ }^{64}$ In this respect the treatment of canonical lyric poets resembled that of the preeminent epic and tragic poets.

\subsection{Stage 5: The Roman Period}

In the Empire, the centre of Greek literary culture is probably Rome, ${ }^{65}$ but the best evidence for the reception of Greek lyric continues to be papyri from Egypt, which confirm what we would otherwise have suspected: that Greek lyric poetry continued to be read and taught in schools in the early imperial period. Papyri of all nine of the canonical melic poets have survived, along with some of Corinna. For the iambic and elegiac poets we have papyri for Archilochus, Hipponax, and Tyrtaeus. Commentaries are also known to have been written, ${ }^{66}$ and it became the practice to include excerpts from these in the manuscripts of poems in the form of scholia. ${ }^{67} \mathrm{~A}$ good example of how commentators may have shaped expectations of readers is provided by a fragment of a commentary on Alcman, P.Oxy. 239o, which argues that Alcman's poem contains a cosmic genealogy, something that may not have been in the poem at all. 68

Greek song continues to be adapted, imitated, and cited in literature. Catullus translates Sappho, and Horace presents himself as introducing Greek song (Archilochus in the Epodes, Sappho and Alcaeus in the Odes) into Rome. ${ }^{69}$ Patricia Rosenmeyer has pointed to Sapphic resonances in the poems of Julia Balbilla, a travelling companion of the emperor Hadrian, inscribed on one of

62 See Gerber (1999) Archilochus T3.17-25; Clay (2004).

63 Callimachus fr. 64 Pfeiffer; see Barchiesi (2009) 327-328; Rawles (2018).

64 Stesichorus: see Barbantani (2010) 29-39; Ibycus: Barbantani (2010) 19-22, referring to $A P$ $7 \cdot 714$.

65 For the shift to Rome, see Irigoin (1994) 73.

66 Commentaries on Pindar and Bacchylides were written by Didymus of Alexandria (late first century CE); see Montanari (2015) 173-174; Braswell (2013); Theon worked on Alcman, Pindar and Stesichorus (Montanari [2015] 178); a section of his commentary on the Pythians survives on papyrus (P.Oxy. 2536: Theon). Tryphon of Alexandria wrote on the dialects of the lyric poets (Montanari [2015] 182).

67 Dickey (2015) 504.

68 See Most (1987).

69 See Paschalis (2002), Feeney (1993). 
the colossi of Memnon in Roman Egypt. ${ }^{70}$ One tendency we observe is for the idea of any particular poet to become simplified, a stereotyping process akin to that which cognitive theorists call "chunking". Thus, Pindar is torrential and overpowering, like a river in full flood (Horace, Odes 4.2.5-8), while Anacreon is reduced to being a poet of the symposium and love, even though his poetry may have been broader than that. ${ }^{71}$

Lyric poets were popular with the prose writers of the Second Sophistic, partly, perhaps, for the stylistic embellishment that excerpts of poetry were seen to provide (see Hermogenes, On Ideas 331, 334 Radt). Plutarch often cites them for moral content, and Athenaeus not infrequently for what they say about the ancient symposium. The treatise De musica ascribed to Plutarch includes accounts of the development of Greek music, much of it culled from Peripatetic writers, with many references to Greek lyric poetry. The rhetor Heraclitus, author of the Homeric Problems, applies allegorical interpretation to Alcaeus and Anacreon. ${ }^{72}$ Pindar becomes something of a religious source book in this period, being cited by, for instance, Pausanias in his guide to Greece and Aelius Aristides in his prose Hymn to Zeus (43.40). In the third century CE, Menander Rhetor recommends several of the lyric poems as models for different types of hymn..$^{73}$ One of the biggest surprises in recent years is the discovery that 'Ibycus of Rhegium' was probably a character in a Greek novel. ${ }^{74}$

\subsection{Stage 6: Late Antiquity and Byzantium}

Continued interest in lyric in the fourth century $\mathrm{CE}$ is shown by the Orations of Himerius, one of which seems to summarize a paean by Alcaeus (Or. 48), while another excerpts Sappho's epithalamia (9). The Emperor Julian uses iambus as a model. ${ }^{75}$ Nonnus makes striking use of the idea, at least, of Pindaric victory odes in his Dionysiaca. ${ }^{76}$

\footnotetext{
$70 \quad$ Rosenmeyer (2008).

71 See Bernsdorff (2014). For “chunking" see Rotstein (2010) 11.

72 Alleg. 4, citing Alcaeus 208.1-9 Campbell and 6.13 Campbell and Anacreon PMG 417. For the ship of state in Alcaeus, see Bowie's contribution to this volume, pp. 286-293.

73 At Treatise 1, 333 (Russell and Wilson [1981] 7-9) he recommends Sappho, Anacreon, and Alcman for cletic hymns, Bacchylides for apopemptic hymns, and Simonides' hymn to Tomorrow is an example of a fictitious hymn. Sappho is a source for narratives about divine marriages (2, 402; Russell and Wilson [1981] 141); Menander's Sminthiakos Logos cites the example of Pindar (2, 437; Russell and Wilson [1981] 207).

74 This is known to us through a Persian translation: see D'Alfonso (2000); Hägg and Utas (2003) 230-231.

75 Hawkins (2014)

76 Hardie (2005)
} 
Despite this, it seems likely that after the third or fourth centuries CE there was a decline in the range of texts in circulation, and that the melic poets gradually ceased to be read-with some exceptions. Sappho remained in circulation for a while (one codex of Sappho, P.Berl. 9722, is dated to the sixth or seventh centuries CE), but not into the later Byzantine period. ${ }^{77}$ Pindar's Epinicia survived, saved by contemporary interest in competitions, most likely; ${ }^{78}$ a commentary on Pindar was written as late as the twelfth century CE by Eustathius of Thessalonica. ${ }^{79}$ Theognis also survived into the Byzantine period, and it is possible that a book of Hipponax was still available in this period as well. ${ }^{80}$ The loss of the texts is to some extent compensated for by anthologies, such as that of Stobaeus (fourth to fifth centuries CE), who includes excerpts from most of the lyric poets, but particularly Theognis: paradoxically, Theognis' popularity as a source for gnomai in anthologies may have been a factor that sustained interest in his works and led to their survival. ${ }^{81}$

2

The Individual Chapters of This Volume

The foregoing must suffice as a chronological sketch within which to situate the chapters of this volume. The chapters themselves have been grouped into seven subsections (' 1 ' to ' 7 ') highlighting distinct aspects of the process, whether thematic (transmission, canonization, reception, scholarship) or temporal (the classical period of the fifth to fourth centuries BCE; the Peripatetic movement of the fourth century BCE; the Roman period; and the Second Sophistic movement of the second century CE). It will be obvious that these divisions are for convenience only. Often more than one period is involved (Stages 1 and 5 are relevant in the contributions of van Hilten-Rutten and Caciagli), and very often more than one thematic aspect of the process of transmission is in play. As the following summaries will make clear, the chapters in many cases offer different and even contradictory perspectives on the same material; this plurality was welcomed.

\footnotetext{
77 See Pontani (2001).

78 Rutherford (2012) 100-104.

79 See Neumann-Hartmann's contribution to this volume; Pontani (2015) 386-387. For even later Byzantine work, see Pontani (2015) 417, 423-425; for Tzetzes' study of Pindaric metre, see Dickey (2015) 49o.

8o See Masson 1962: 42-51; Degani (1984) 8o-83.

81 See Campbell (1984).
} 


\subsection{Part 1: Transmission}

André Lardinois, in 'New Philology and the Classics: Accounting for Variation in the Textual Transmission of Greek Lyric Poetry', advocates for ancient Greek lyric a methodology (the New Philology) developed by scholars of medieval European literatures. The traditional aim of the modern editor of reconstructing the "original" text of a Greek lyric poem comes under scrutiny here: what if our textual witnesses take us back to a time when there was no "canonical" version of the text (compare above on Stage 1)? Do we hope to be able to intuit the author's original text, or do we content ourselves with presenting all alternatives as equally valid? Even when we are confident that one version is "authentic", does that mean that "less authentic" versions that were current in antiquity should be disregarded? Lardinois surveys a number of texts that illustrate the challenges, from Solon, Theognis, Tyrtaeus, Alcaeus, and Sappho. At the heart of Lardinois' chapter is the interplay between notions of canonization (in the sense of the creation of fixed texts), and of reception (in the sense of ancient reworkings of that text). Lardinois makes the case that ancient reworkings should be an object of study as much as the canonical text itself. We are required to ask ourselves whose text we are interested in: the author's own, some later "authorised" version, or all versions that speak to the changing significance of the author and his or her text throughout antiquity? Depending on our perspective, each may have a particular claim on our attention. Also central to this discussion (as to many others in the volume) is the question of the relative value of the indirect tradition compared to the direct tradition.

The method of the New Philology is explored in detail through a single test case by Eveline van Hilten-Rutten in 'Tyrtaeus the Lawgiver: Plutarch and Diodorus Siculus on Tyrtaeus fr. 4'. Tyrtaeus' poem about the origins of the Spartan constitution as it appears in modern editions is a conflation of different versions transmitted by two historians, who cite it for different reasons. Van Hilten-Rutten questions whether Plutarch and Diodorus are best treated as two testimonia to a single original whose reconstruction should be scholarship's goal. The point here is not that there is no original and that we should resign all hope of recovering it (though the difficulty of that task is not underestimated). It is rather that our task should also be to strive to appreciate the palimpsestic quality of these texts as preserved in the indirect tradition, the layers of interpretation they have accrued in antiquity. Van Hilten-Rutten investigates the specific interpretations given to the Tyrtaean passage by Plutarch in his Life of Lycurgus and by Diodorus in an excerpt from the lost seventh book of his World History. Plutarch, she argues, seeks corroboration in Tyrtaeus' text of his own account of how a 'rider' was added to the Lycurgan 'Great Rhetra' by the two Spartan kings Polydorus and Theopompus, on the authority of the Delphic 
oracle; van Hilten-Rutten shows how Plutarch presses various indeterminacies in Tyrtaeus' language into the service of his interpretation. In the case of Diodorus, we have an excerptor excerpting Diodorus quoting Tyrtaeus, and the ten elegiac verses quoted are in fact introduced as being not of Tyrtaeus, but of an oracle (a rather extreme form, therefore, of the "excarnation"82 of the work of a lyric poet). The Diodoran excerptor appears to have been interested in the elegiac verses as a memorable expression of the need for obedience to authority. Diodorus' own reasons for including the quotation of Tyrtaean in his History are less apparent; van Hilten-Rutten suggests that he may have been interested in citing poetic testimony to buttress his historical account of the laws and oracles of Lycurgus or for their moralizing content.

\subsection{Part 2: Canons}

Whereas the first two chapters addressed the question of fixed texts, the following are additionally concerned with the creation of a canon in the sense of a fixed list of supreme poets and/or poetic genres. Gregory Nagy's chapter, 'On the Shaping of the Lyric Canon in Athens', treats the establishment of both a fixed group of nine "canonical" lyric poets and of fixed "canonical" texts of those poets. He is interested, moreover, in the shift from performance to text, and in the role of fifth-century Athens as a crucial mediating stage in the lyric tradition before the Alexandrians. ${ }^{83}$ Nagy diverges from U. von WilamowitzMoellendorff's classic discussion of the Greek lyric textual tradition in conceiving of the "lyric canon" as a phenomenon of the performative tradition before it became one of the textual tradition. ${ }^{84}$ The canonization of the 'lyric nine', Nagy argues, was due to the Panathenaic performance repertoire: this fed into and informed Alexandrian tradition, which, however, abandoned the performative aspect. The parallelism between epic and lyric is key: the Homeric epics and the "lyric nine" were both performed at the Panathenaea: Nagy points to inscriptional and literary evidence for competitions at the Panathenaea of rhapsodes performing Homeric epic and of kitharodes and aulodes performing lyric. The institution of rhapsodic contests at the Panathenaea saw the two "Homeric" epics, the Iliad and the Odyssey, being made "canonical", in the sense of both being accorded a specially privileged status vis-à-vis other early epic poems and of becoming textually fixed via the so-called "Pisistratean recension". A parallel development for lyric is envisaged, whereby texts of the "lyric nine" were generated primarily from performance at the Panathenaea. The Alexandrians

82 See above, p. 1.

83 This is also a concern of the contributions to this volume of Calame and Bartol.

84 Wilamowitz (1900). 
will have inherited this Athenian legacy, though not merely passively: we may think of them also as proactively expanding what came down to them, their collecting activities thus counterbalancing a probable narrowing of the Panathenaic performance repertoire of the lyric poets that set in around the first half of the fourth century вСE. Thus Nagy posits continuity between Athens of the fourth to third centuries BCE and third-century BCE Alexandria in scholarly and textual activity on the canonical representatives of all the three main poetic genres: Homer (for epic), Aeschylus, Sophocles, and Euripides (for tragedy), and the "Nine" (for lyric). That continuity in the scholarly-critical tradition is accompanied by discontinuity, however, in the performance tradition, which Nagy regards as ceasing with classical Athens. ${ }^{85}$

Claude Calame, in 'Melic Poets and Melic Forms in the Comedies of Aristophanes: Poetic Genres and the Creation of a Canon', looks at the evidence from Old Comedy for the reception of lyric poetry in late fifth-century BCE Athens. He finds that the notion of the nine canonical lyric poets of Alexandrian scholarship has no very clear adumbration in extant Aristophanic comedy or Old Comedy more generally. Five of the nine are mentioned by Aristophanes, and three others by Eupolis (with only Bacchylides going unmentioned), but non-canonical, especially dithyrambic, poets are also named (such as Lasus of Hermione, Cinesias, and Philoxenus). There is, moreover, no very clear articulation of the lyric "genres" that are fundamental to later Alexandrian scholarship. Rather, as Calame shows, several genres were clearly distinguished in the fifth century (and others might easily have been); but certain others (such as the skolion and the 'Harmodius song') eluded distinctive labelling, while others again (such as iambus and elegy) ${ }^{86}$ were intrinsically not such as to submit to easy categorization. The Aristophanic evidence also offers other insights into the reception of lyric in Athens of the later fifth century. First, the symposium emerges as the key venue for the reperformance of melic poetry (most explicitly, in the scene involving Strepsiades' request for Simonides' Krios-ode from Pheidippides in Clouds). Second, we may see evidence of the phenomenon referred to in this introduction as "chunking", the tendency to reduce the significance of the lyric poets to just one or two salient aspects; thus Ibycus, Anacreon, and Alcaeus are associated in comedy with the singing of (homo-)erotic praise at symposia (for instance, in the Agathon scene of the Thesmophoriazusae). Third, a crucial component of comedy's (and likewise tragedy's) reception of lyric poetry consists not in what Calame calls 'simple

85 On the question of the (dis)continuity of the performance tradition, see also D'Alessio (2017).

86 See Bartol's contribution to this volume on elegy. 
"allusions" to traditional melic forms', but in the novel creation of melic compositions for fictional ritual occasions that arise from the comic (or tragic) plot (for instance, the hymenaia at the end of Birds and Peace, or the paeanic songs found in Thesmophoriazusae and several other comedies). In all this, Calame stresses the importance of the fifth-century вСе Athenian song and dance culture (which itself represents a departure from the various epichoric song and dance cultures in which the traditional melic compositions came about in the first place) that fostered a flexibility and suppleness quite unlike the rigid systematization necessitated by the Alexandrian editorial project.

Krystyna Bartol, in 'Structuring the Genre: the Fifth- and Fourth-Century Authors on Elegy and Elegiac Poets', deals with the reception not of specific poems or poets but of a genre-elegy - in the classical period. Like Calame, she emphasizes that the fifth and fourth centuries represented a crucial transitional moment in the transmission of lyric, but differs somewhat from Calame in finding both performance and texts vital to the ways in which the conceptualization of elegy as a distinct genre evolved during this period. First, she considers the distinction of elegy from melos. While elegiac poetry was always distinguished from melic poetry, the basis of the distinction appears to have shifted. In the earlier period, both were conceived of as being sung and performed, though to a different musical accompaniment; later, the distinction turned into one between a sung genre (melic) and a recited one (elegiac). Second, Bartol examines the evolving understanding of the term elegos: originally a term relating to performance (apparently a particular melodic pattern suiting the metrical form), it came to be conceived, apparently from the later fifth century onwards, in terms of content (the lament). Third, Bartol considers the connotations of the term elegeion: towards the end of the fifth century, it seems to conjure up, in addition to its metrical scheme, a particular type of content: both praise poetry (thus we find elegeion as praise poetry being opposed to iambos, blame poetry) and paraenetic poetry. Fourth, Bartol reflects on the assumptions that underlie the creation of elegiac collections from an early date (at least the late fifth century $\mathrm{BCE}$, and perhaps as early as the late sixth century $\mathrm{BCE}$ ). The poems in these collections all relate to a sympotic context (as indeed do other, non-elegiac, anthologies); ${ }^{87}$ but crucially, further to the metre and the sympotic ambience, they evidence paideutic, didactic, or gnomic content of a kind relevant to aristocratic education. Bartol points out that such early elegiac anthologies presuppose the sophistic distinction between collections

87 Compare Caciagli's contribution to this volume, p. 327. 
made for pleasure and those made for edification. ${ }^{88}$ In these elegiac collections we may again see the operation of "chunking": long narrative elegies are excluded, and only the shorter, sympotic, paraenetic, and paideutic poems are seen as elegy's canonical representatives by classical authors. Bartol's emphasis on the importance of written anthologies in the fifth century for the development of the classical conception of the elegiac genre can be contrasted with Calame's emphasis on performative factors for the fifth-century conceptions of genre.

\subsection{Part 3: Lyric in the Peripatetics}

Scholarship on the Greek lyric poets is especially associated with the Alexandrian critics of the Hellenistic period, but the lyric poets were already a concern of the Peripatetic philosophers of the fourth century вСE. In 'The Peripatetics and the Transmission of Lyric', Theodora Hadjimichael documents the "Peripatetic project" in relation to the lyric poets, focussing on such figures as Heraclides Ponticus, Dicaearchus, Chamaeleon, Praxiphanes, and Aristoxenus. The school produced treatises both on individual lyric poets and treatises of a more general nature. Characteristic features of this "project" as a whole are its complementarity (reduplication of the work of other members of the school was apparently avoided) and its aesthetic conservatism. Hadjimichael's discussion raises important questions about the transmission and canonization of lyric, touching on many of the issues that were central to the discussions of Nagy and Calame. First, take canonization: the lower chronological cut-off point for "canonical" lyric poets applied by the Peripatetics is the second half of the fifth century вСЕ (thus excluding New Music - apart from Aristoxenus on Telestes). Hadjimichael sees this as an example of the Peripatetics' pursuit of a conservative "classicized" agenda, influenced by Platonic (and Old Comic) views, which favoured the traditional and spurned the innovative. Next, transmission: Hadjimichael, focussing on the Peripatetics, finds Athens relatively unimportant to the transmission of lyric, inferring that the Peripatetics, though resident in Athens, relied on lyric texts obtained from elsewhere. This perspective contrasts with that of Nagy who, focussing on the Panathenaea, accords Athens a central position in the transmission of lyric to Alexandria. According to Hadjimichael, moreover, the Peripatetics did not themselves 'organise, classify, or edit the text of lyric', although editions were a prerequisite of their scholarly work. Members of the "Lyric Nine" whom the Peripatos ignored include

88 For the impact of sophists on fifth-century вСе lyric poets themselves, compare Fearn's contribution to this volume, pp. 226-234, on Gorgias and Timotheus. 
Ibycus and Bacchylides; these may have lacked editions, or at least the Peripatetics would appear not to have possessed them. Alternatively, it is possible, Hadjimichael suggests, that Ibycus and Bacchylides were not seen as "classical", next to, respectively, Anacreon and Pindar. (We may here compare and contrast Calame's discussion, from the evidence of Old Comedy, of which poets were considered canonical in the fifth century.) A further question arises concerning the influence of the Peripatetics on the subsequent critical tradition. Hadjimichael sees the Peripatetics as initiating the properly "literary study" of lyric poetry, rather than merely philosophical or historical uses of it, as seen, for instance, in Plato or Herodotus. This development would then eventually pave the way for the great commentaries of Aristarchus and Didymus and, ultimately, of Eustathius. ${ }^{89}$

Elsa Bouchard's appraisal of the Peripatetics in 'The Self-revealing Poet: Lyric Poetry and Cultural History in the Peripatetic School' turns in a different direction to Hadjimichael's. In her view, the Peripatetics were not interested in the lyric poets (as they were in Homer) from a genuinely literary critical perspective. Instead, they attached to them a 'historical value', and used them on the one hand to create an account of the origins and the successive innovations in the art of mousike (illustrations are given from Chamaeleon and Clearchus) and on the other to exemplify the moral character and cultural practices of the early Greeks. For Bouchard, this 'antiquarian interest' can account for the Peripatetic disinterest in the New Music: the relatively late date of these poets meant that they could not serve as witnesses to the earlier period. (We may compare and contrast the 'classicized agenda' attributed to the Peripatetics by Hadjimichael, seeing the aesthetic conservatism of the school, following Plato and Old Comedy, as responsible for the exclusion of the New Music from the Peripatetic "canon".) Compared with Hadjimichael, Bouchard also downplays the influence of the Peripatetics on the Alexandrians, regarding the more distinctively literary and formalistic approaches to lyric poetry of the latter as lacking anticipations in the former (whereas Hadjimichael saw the Peripatetics as paving the way to the properly literary study of lyric). Bouchard bolsters her case with two further arguments. First, the Peripatetic attitude towards lyric poetry is related to that of Aristotle, who was disinterested in lyric poetry as poetry because it was non-mimetic (the lyric poets, unlike Homer or the tragedians, spoke in their own persona). And second, Chamaeleon's trademark biographically oriented criticism (the so-called "Chamaeleon's method", which

89 On Aristarchus and Didymus, see Phillips' contribution to this volume, pp. 441-45o. On Eustathius, see Neumann-Hartmann's contribution to this volume. 
takes the poet's text to give a window on the poet's life and vice-versa) is applied exclusively or at least pre-eminently to the lyric poets, rather than to the early hexameter poets or the tragedians.

\subsection{Part 4: Early Reception}

The New Music that was excluded from the treatises of the Peripatetics is the subject of David Fearn's chapter, 'Lyric Reception and Sophistic Literarity in Timotheus' Persae', where canonicity and reception also play central roles. Fearn illustrates how 'Platonic reactionism' is not just a feature of the reception of Timotheus by the Peripatetics (compare Hadjimichael's paper), and by the ancients more generally, but also of modern scholars and editors, such as Bacchylides' great Victorian editor, Richard Jebb; in both antiquity and modernity the canonical Bacchylides, though himself often denigrated in comparison to Pindar, enjoyed a respectability and admiration denied to the non-canonical Timotheus. However, the divergent treatment of the two poets in terms of ancient literary criticism and transmission history is only one part of the picture. A contrasting picture is implied by "literary history"; that is, by the poetic reception of the former by the latter. Through a study of Timotheus' intertextual, structural, and stylistic debts, Fearn reveals Timotheus as a self-styled continuator of the lyric, and especially dithyrambic, traditions found in Pindar and Bacchylides; the continuities are no less important than the discontinuities between the "canonical" and "non-canonical" poets. Fearn goes on to explore Timotheus' debts to the sophist Gorgias, as indicative of the complexity and self-consciousness of Timotheus and the range of his influences. Fearn's argument also shows how, as early as Timotheus, lyric poets may be responsive to the scholarly and critical tradition of which Gorgias in the Helen is an early representative. Much later, we see Horace and other Latin poets responding to Alexandrian scholarship on the Greek lyric poets. ${ }^{90}$ This shows that the scholarly philosophical "paratext" can turn into something more like "intertext" even in the context of late fifth-century lyric.

Reception and canonization are likewise fundamental to Andrea Capra's “"Total Reception": Stesichorus as Revenant in Plato's Phaedrus'. Capra reveals that Plato's reception of Stesichorus in the Phaedrus is more pervasive than previously recognized; Stesichorean pastiche already bookends Socrates' first speech (237a7-9, 241di) prior to his explicit quotation from Stesichorus' 'Palinode' (243a6-9). Capra is interested above all in the contrast that Socrates draws between Stesichorus and Homer (243a4), which Capra interprets as a multifa-

90 See the contributions to this volume of Bowie and Bitto. 
ceted programmatic opposition that gets developed at the end of the dialogue in particular $\left(27 \mathrm{e}^{\mathrm{e}} \mathrm{b}^{-\mathrm{b}} \mathrm{2}\right)$. In the terms of this opposition, Homer is associated, via the rhapsodes, with fixed texts (whether written or performed, verse or prose - as with the speech of Lysias with which the dialogue begins), with the ignorance of true causes, and with (metaphorical) blindness. Stesichorus, on the other hand, is associated with musical performance, flexibility, dialectical discourse, knowledge of true causes, (metaphorical) sightedness. Accordingly, on Capra's interpretation, the 'fixed impersonal discourse' of (the rhapsodes') Homer is unfavourably compared to the 'flexible personal speech' of the lyric poet Stesichorus. (Here we may note the contrasting valorization of the opposition of a 'mimetic' Homer versus 'non-mimetic' lyric poets that was found by Bouchard in the Aristotelian and Peripatetic school.) In this introduction we have discussed the transformation of lyric from a musical performance (in the archaic and classical periods) into a fixed written text lacking musical notation (in the Hellenistic period); ${ }^{91}$ Socrates, according to Capra, in the later fifth century is interested in the difference between lyric poetry as a musical performance and Homeric poetry as a fixed text memorized and recited by rhapsodes. Capra, like Nagy, is also interested in the performance of Stesichorean lyric at the Panathenaea alongside rhapsodic performance of Homeric epic. But Capra's argument emphasizes the opposition between a "musical" Stesichorus and a non-musical (fixed-text-dependent) rhapsodes' Homer, while Nagy's argument stresses a parallelism between Homer and the lyric poets in that both become "canonical" (in both senses in which we are interested) as a consequence of the Panathenaea. According to Capra, Plato also has Socrates in the Phaedrus make play with the idea of "canonization" in the sense of a selection of poets worthy of cultivation for posterity. Rather as Socrates in the Republic indulges the fantasy of a radically unorthodox "canonization" (Homer and the tragedians being excluded from his model republic), here too he implies a "canon" of value in which Stesichorus surpasses Homer and he himself surpasses Stesichorus. Capra also stresses the interconnectedness of Stesichorus' text (that of the 'Palinode') and paratext (in the form of the biographical tradition of Stesichorus). We are dealing with a case of reception on all fronts-what Capra calls 'total reception': ${ }^{2}$ namely, verbatim quotation, pastiche, metrical allusion, and allusion even (Capra suggests) to the way Stesichorus' poems would have been acted out in performance.

91 Above, pp. 8-9.

92 Compare Calame's contribution to this volume, p. 123, on Aristophanic comedy's 'full-scale dramatization of lyric poetry, enacted both musically and ritually in the orchestra.' 
With Maria Kazanskaya's chapter, 'Indirect Tradition on Sappho's kertomia', we move from the biographical tradition of Stesichorus' blinding in Plato (Capra, above) to the biographical tradition of Sappho apparently taking her brother Charaxus to task for his love affair with a courtesan from Naucratis. Kazanskaya is concerned with divergences on three points in the indirect tradition (comprising statements from Herodotus, Posidippus, Athenaeus, and Ovid): first, the name of the courtesan (whether Doriche or Rhodopis); second, the tone of the poem (whether hostile or friendly); and third, the butt of the censure (whether the brother or the courtesan). There are some methodological similarities here with van Hilten-Rutten's chapter, in that Kazanskaya pays close attention to the indirect tradition and is concerned with the question of how elements of an original archaic lyric poem may be reconstructed from the indirect tradition. However, here the poet's ipsissma uerba are not at stake, but rather the coarser-grained issue of the outline of the poem's content. Moreover, whereas van Hilten-Rutten's New Philological approach was premised on the impossibility or undesirability of establishing a unitary original text, the object here is to read the various authors of the indirect tradition in such a way as to reconcile the differences and so to establish the likely contours of Sappho's lost poem. Thus, Kazanskaya feels able to infer that in Sappho's poem the sister's tone was admonitory towards Charaxus, but more outright hostile towards the courtesan; that the butt of Sappho's more biting censure was the courtesan, not Charaxus; and that the name of the courtesan was Doricha, not Rhodopis.

\subsection{Part 5: Reception in Roman Poetry}

In 'Alcaeus' stasiotica: Catullan and Horatian Readings', Ewen Bowie looks at how two Roman poets engage with Greek lyric poetry, specifically Alcaeus. The first case is Catullus' poem 11, the renunciation of Lesbia, which scholars assume is intended to recall Sappho; without disputing that, Bowie argues that the poem is rather a 'brilliant collage' that evokes both Alcaeus and Sappho. The argument has interesting implications for (once again) the way that "chunking" applies to the Greek lyric poets: we tend to think of Sappho as being "chunked" in Rome as a personal, amatory, feminine voice, well suited to Catullus' countercultural neoteric poetic programme; and to think of the Augustan lyric poet Horace as pointedly preferring the ostensibly more politically engaged and masculine persona of Alcaeus. However, Bowie's reading of Catullus 11 prompts a nuancing of this account. Not only do the Alcaic and Sapphic elements jostle with one another in Horace's construction of his lyric persona, they do so already in Catullus. The second poem Bowie considers is Horace Odes 1.14, in which the image of a ship in sea during a storm serves as a political allegory. According to a standard position in modern Horatian and 
Alcaean scholarship, Horace's allegory is derived from a corresponding allegory in poems of Alcaeus, detected already by Heraclitus in his Homeric Problems. Bowie indicates, however, that a non-allegorical interpretation of Alcaeus is also viable, and goes on to point out that Horace in two further odes (1.32 and 2.13) uses the shipwreck image non-figuratively. Granted that Horace as poeta doctus was familiar with the commentary tradition on the Greek lyric poets as well as with the poets themselves, ${ }^{93}$ Bowie argues that in Odes 1.14 and 1.32 Horace reflects alternative approaches in Hellenistic scholarship to Alcaeus' storm-tossed ship: allegorical and non-allegorical respectively. Thus, consideration of Horace's reception of Alcaeus invites a reappraisal of Hellenistic scholarship on Alcaeus, which in its turn has implications for our interpretation of Alcaeus' own poetry. This particular case study therefore provides a fine illustration of how our interpretation of the text of an archaic melic poet (Alcaeus) can be dependent both on our reconstruction of the ancient scholarly paratext (the Hellenistic commentary tradition) and on our gauging of the poet's reception by other poets in the lyric tradition (here, Horace).

Similar issues, in connection with Pindar rather than Alcaeus, are the concern of Gregor Bitto's 'Pindar, Paratexts, and Poetry: Architectural Metaphors in Pindar and Roman Poets'. Bitto traces successive receptions of Pindar's architectural metaphor, 'a treasure-house of songs' (Pythian 6.7) through Horace, Propertius, Ovid, and Statius. Bitto shows that, alongside the elaborate windowreferencing and contrast imitation at work in this series of poetic receptions, when these Roman poetae docti hark back to the Pindaric original they are engaging not just with the text of Pindar itself, but also and just as vitally with its paratext, the Hellenistic scholarly tradition that had grown up around the Pindaric text. Thus, some of the changes rung on the extended Pindaric image are seen by Bitto as having been prompted by Hellenistic scholarly judgements (which have left traces in our Pindar scholia) on the aesthetic merits and demerits of the passage. But the Hellenistic literary critical aesthetic is used very creatively by the Latin poets: Horace's reworking of Pindar gestures assentingly to it, whereas Statius' reworking pointedly flouts it. Bitto also invokes the commentary tradition to argue that Virgil in his famous architectural metaphor (the poem as a temple) in the proem of the third Georgic is engaging substantively with Pindar (or rather, with the assemblage that is Pindar plus his ancient commentators), and not merely with Callimachus' Pindarizing epinician, the Victoria Berenices.

93 See also Bitto's contribution to this volume, p. 300. 


\subsection{Part 6: Second Sophistic Contexts}

Stefano Caciagli's contribution, 'Sympotic Sappho? The Recontextualization of Sappho's Verses in Athenaeus', examines the use of the indirect tradition of Sappho's poetry to determine the original circumstances of the performance of Sappho's poems and the nature of her relationship to her 'companions' (hetairai). The idea that Sappho was a schoolmistress has been generally rejected as being a fabrication of the scholia, with many scholars today, Caciagli included, being more open to seeing her female addressees as a group of comrades (hetairai) on the analogy of Alcaeus' symposiastic hetairoi. But the construction of this "sympotic Sappho" has tended to rely on a privileging of the poetess's ipsissima uerba over the testimonia, a procedure that Caciagli now identifies as problematic: neither our implicit trust in the former nor our instinctive distrust of the latter are fully justified. Caciagli's discussion once again revolves around the relationship of text and paratext, although here the manner of the transmission of the poetry complicates even that distinction. On the one hand, as Caciagli points out, Sappho's poems may have been transmitted from archaic and classical times in anthologies for use at symposia. On the other, an embedding text such as Athenaeus' Learned Banqueters quotes excerpts of Sappho in the context of a narrative setting that is explicitly sympotic. Thus the ipssima uerba of Sappho that come to us through these routes are likely to come with a sympotic veneer that may owe nothing to the original circumstances of Sapphic performance (a kind of double form of "excarnation", therefore). So, Caciagli argues, with Sappho fr. 94, Athenaeus' manner of quoting creates a sympotic impression that may not have been present, either at all or to the same degree, in the original. ${ }^{94}$ And in Sappho fr. 2, Caciagli detects reworking of the Sapphic original either by Athenaeus or his putative source-perhaps a sympotic anthology. The discussion leaves our confidence shaken in reconstructions of a "sympotic Sappho" (that is, a Sappho with a female hetairia analogous to Alcaeus' male hetairia) on the basis of the-assumed-ipsissima uerba as given by Athenaeus: these are liable to the suspicion of having been reworked precisely so as to accentuate the sympotic aspects. Although Caciagli still cautiously favours the idea of Sappho's having had such a female hetairia, he here counsels caution in the use of the fragments quoted by Athenaeus in order to reach such a position.

Renate Schlesier, in 'A Sophisticated hetaira at Table: Athenaeus' Sappho', shares with Caciagli interests in Athenaeus' presentation of Sappho, Sappho's relationship with the symposium, and the interpretation of Sappho's status as

\footnotetext{
94 For the point, see Schlesier's contribution to this volume, p. 367, citing Jacob (2013).
} 
hetaira; however, her discussion moves in different directions. On Caciagli's reconstruction of Athenaeus' Sappho, hetaira means 'fellow-member of a (female) aristocratic faction', analogously to Alcaeus' use of hetairos of his male companions, and the symposia envisaged are female equivalents of the male symposium seen in Alcaeus' poetry. On Schlesier's reconstruction of Athenaeus' Sappho, hetaira means 'courtesan' and the symposia are male drinkingparties to which the only women admitted as active participants were courtesans. After surveying the many references to and quotations of Sappho in Athenaeus, Schlesier identifies the symposium as a 'thematic frame' for Athenaeus' quotations of Sappho. From book 9 on, and especially in book 13, Sappho is associated with eroticism. Most Sapphic quotations come in book 13, where the discussion centres on courtesans (hetairai). Athenaeus' learned banqueters see Sappho, Schlesier argues, as participating in male symposia as a courtesan, and she is viewed as being as much at home in the context of the (male) symposium as male lyric poets, such as Anacreon. Further, Athenaeus' learned banqueters treat Sappho as a courtesan by freely admitting her into the literary and cultural space of their own symposium, in which she becomes a virtual participant. Schlesier argues further that the attributes and utterances of Sappho that receive prominence in the Learned Banqueters are consistent with a courtesan, and points out that Athenaeus' representation of Sappho as a courtesan is consistent with other strands of Sappho's reception in antiquity. This leaves open the question of how this view of Sappho's status relates to the seventhcentury BCE reality, and how it should inform our interpretation of Sappho's poetry-questions that Schlesier has pursued more explicitly elsewhere. ${ }^{95}$

In 'Solon and the Democratic Biographical Tradition' Jessica Romney is interested in the way the ancient reception of Solon, in the form of the biographical tradition that starts in the fifth and fourth centuries BCE and culminates in Plutarch's Life of Solon in the first to second centuries $\mathrm{CE}$, has conditioned the interpretation of his poetry as transmitted in the indirect tradition. Romney thus takes a similar approach to Plutarch's presentation of Solon as does Caciagli to Athenaeus' presentation of Sappho. Like Caciagli, Romney is interested in how the 'narrative frames' provided by source-authors dictate our understanding of the fragments. Her approach also invites contrast with the New Philological approach undertaken by Lardinois and van Hilten-Rutten; while they insist on the validity of the source-authors' readings (both their textual readings and their interpretative readings) of the lyric poets as an object of study in its own right, Romney's aim with the source-authors on Solon is to 'destabilize this tra-

95 See, e.g. Schlesier (2013) 217. 
dition, contextualizing the fragments in the setting of archaic politics as seen in the Greek poleis as a whole. Whereas the biographical tradition persistently presents Solon as an isolated, moderate, and mediating figure, standing above the factionalism of contemporary Athenian politics, Romney argues that Solon is much more likely to have been implicated in the stasis of his city-state and to have been the leader of a hetaireia, analogously with near-contemporary figures such as Alcaeus. Thus in fr. 11, rather than berating 'the Athenians' on allowing Pisistratus' tyranny, as the indirect tradition (Diodorus, Diogenes Laertius, and Plutarch) would have it, Solon is more likely, Romney argues, to be addressing his hetairoi (the members of his hetaireia). The pronouns used by Solon

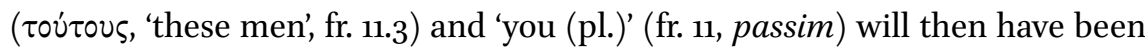
accommodated by these source-authors to their own reading where they are referred to, respectively, Pisistratus and 'the Athenians' at large, rather than to a rival hetaireia and Solon's own hetaireia. ${ }^{96}$ Similar points may be made about the reference of the pronominal adjective in Solon fr. 4.1 $\dot{\eta} \mu \varepsilon \tau \varepsilon \dot{\varepsilon} \eta \ldots$... $\pi$ ó $\lambda ı$, and about the contrasting of i $\dot{\mu \varepsilon i \varsigma ~ ' w e ' ~ w i t h ~ a u ̉ \tau o i ̂ ~(a s ~ r e a d ~ b y ~ P l u t a r c h: ~ v . l . ~ \tau o u ́ \tau o เ \varsigma) ~}$ in fr. 15.1-2; similar oppositions, Romney points out, are found in Alcaeus. Romney thus shares with Caciagli the insight that the ipsissima uerba of the poet are affected by the way that the poet is presented in the indirect tradition.

The Solonian biographical tradition and the indirect tradition of Solon's poetry in Plutarch are again the subject of Jacqueline Klooster's paper, 'Strategies of Quoting Solon's Poetry in Plutarch's Life of Solon'. Whereas Romney concentrates on how the vision of Solon's role in democratic Athenian politics has shaped Plutarch's reception of Solon, Klooster focusses on how Plutarch's moralistic approach both to the study of poetry and to the writing of the lives of exemplary men has conditioned his reception of Solon. Plutarch's moralizing attitude to poetry is set out in his tract How to Study Poetry, where he accords poetry a definite value as a propaedeutic to the study of philosophy, but also recognizes that there are many potentially pernicious features of poetry, and recommends various hermeneutic strategies for neutralizing these. Klooster points out that Plutarch employs several of these strategies in his treatment of Solon's poetry, not merely in the Solon, but also in the Amatorius and Conuiuium. One key strategy is that of offsetting an immoral passage with another more edifying passage from the same author. This is found in Solon 3.1, where Plutarch alludes to (but, significantly, does not quote from) poems of Solon that bespeak an extravagant and hedonistic lifestyle, but then offsets these

96 Compare van Hilten-Rutten's contribution to this volume, pp. 78-79, on Plutarch's reinterpretation of the unexpressed subject of the participle $\dot{\alpha} x o v ́ \sigma \alpha \nu \tau \varepsilon \varsigma$ in Tyrt. 4.1. 
with a Solonian quotation in which the first-person speaker (taken to be Solon) professes poverty and virtue. Similarly in Plutarch's Amatorius, a fragment of unabashedly pederastic content (fr. 25) is offset with a fragment (fr. 26) that is interpreted (tendentiously) by Plutarch as expressing the older Solon's commitment to marriage and philosophy. That fragment, moreover, can only be given the desired meaning by implementing another of the strategies outlined in How to Study Poetry: the expedient of interpreting the gods' names metonymically rather than literally: when Solon's first-person speaker professes a devotion to Aphrodite, Dionysus, and the Muses, this is to be interpreted not as a devotion to wine, women, and song, but as a commitment to congenial social interactions ('Aphrodite' and 'Dionysus') and a cultured education (the 'Muses'). Thus, Plutarch's reception of Solon may be influenced not only by the democratic-political colouring inherited by Plutarch (according to Romney's discussion), but also by the sanitizing attitude to poetry held by Plutarch and expounded in his How to Study Poetry. This sanitizing attitude affects not merely the way Plutarch interprets Solon's poetry, but also his reasons for quoting it or, indeed, for not doing so (a form of censorship): the existence of a body of erotic poetry by Solon is alluded to, but scarcely ever quoted from.

No writer of this period had a more intense engagement with Greek lyric than Aelius Aristides, who composed paeans in praise of Asclepius, but in his Hymn to Sarapis claimed that his prose hymns were superior to hymns by the classic poets. In 'Playing with Terpander \& Co.: Lyric, Music, and Politics in Aelius Aristides' To the Rhodians on Concord', Francesca Modini examines a neglected aspect of his use of Greek lyric, namely his presentation of himself as a poet from outside sent to reconcile a community on the model of Terpander.

\subsection{Part 7: Scholarship}

Our main source for ancient scholarship on lyric poems are scholia in manuscipts and papyri, which draw on, among other things, the great Hellenistic commentaries of the likes of Aristarchus and Didymus; the scholia on Pindar's Epinicia are the subject of the chapter by Tom Phillips, 'Historiography and Ancient Pindaric Scholarship'. Bowie and Bitto considered implications of the fact that the Roman 'learned poets' read the Greek lyric poets-specifically, Alcaeus and Pindar-in conjunction with the Hellenistic commentary tradition. In a similar vein, Phillips explores what it could have meant for Hellenistic readers of Pindar's Epinicia of the second to first centuries BCE to encounter Pindar's text via the commentaries. Phillips focusses in particular on how notes that sought to provide historical context for Pindar's poems or that cited his- 
toriographical texts may have affected the reading experience of Pindar's Hellenistic readers. Two kinds of case are distinguished: those where commentators advanced a historicizing reading for a specific exegetical purpose, and those where commentators proffered incidental background historical information without any such purpose. Examples of the first category are scholia on Olympian 3 and Nemean 1, deriving from Aristarchus and Chaeris respectively, where historical contextualization is used to solve problems of seeming irrelevance in the odes. Thus the Dioscuri are invoked (rather than Heracles) at the beginning of Olympian 3 because they enjoyed an important cult in Acragas. In Nemean 1, the 'Heracliscus' myth and Tiresias' prophecy of Heracles' exploits are narrated because the historical circumstances of the laudandus Chromius' life offered certain parallels to that of Heracles. Phillips emphasizes how such notes, rather than closing down the interpretative possibilities, could serve to stimulate critical reflection on the reader's part. The adjective $\varphi \imath \lambda \circ \xi$ sivoเs applied to the Dioscuri in Olympian 3.1 prompts reflection on the possible relationship between an Acragantine Theoxenia festival in honour of the Dioscuri and the circumstances of the ode, while the reader of Nemean 1 is required to consider which elements in Heracles' career correspond to elements in Chromius' and which do not. Examples of scholia that furnish historical information without any explicit interpretative end in view are found in the notes on Olympian 13.23 (where Pindar refers to Corinth's military excellence in very general terms) and Nemean 3.13 (where Pindar refers to Myrmidons as ancient inhabitants of Aegina). In the former instance, the commentator cites a very specific story concerning Corinth's role in the Persian wars taken from the fourth-century ВСЕ historian Theopompus and also attested in a fifth-century epigram of Simonides; Phillips speculates that the aim is to make Pindar more accessible by connecting him with a major Panhellenic event, and suggests that the citation of Simonides is an attempt to encourage the reader to approach Pindar through fifth-century rather than Hellenistic interpretative horizons. In the latter instance, the commentator supplements Pindar's own sober and elliptical reference to the Myrmidons in Aegina's early myth-history by quoting an unabashedly mythical narrative in 'Hesiod's' Catalogue of Women, where Zeus turned all the ants of the island into men and women, followed by a resolutely rationalizing account given by a local historian, Theogenes. Phillips suggest that one effect of the note is to prompt reflections on the relationship, on the one hand, between the archaic epic poet Hesiod and the classical lyric poet Pindar, and, on the other, between the rationalizing-euhemerizing historian Theogenes and the mythological poet Pindar (who in the same ode goes on to give a miraculous account of Achilles' early life). But, once again, the reader's own responses to Pindar's text are not trammelled by what he encounters in the 
commentary tradition: 'The extant scholium does not formulate how text and metatexts should be related, opening up a space for individual readers' interpretative decisions'.

Perhaps the single most significant paratextual device used in the transmission of Greek lyric is the title; in 'Poem-titles in Simonides, Pindar, and Bacchylides', Enrico Prodi presents an in-depth study of the attested poemtitles of these poets. In general, poem-titles can be regarded as a feature of the "canonical" Alexandrian editions of Simonides, Pindar, and Bacchylides, and so this investigation pertains to what we have called "Stage 4" of the transmission of Greek lyric. At this stage in the transmission, the poems were read as texts rather than experienced in performance, and so the title offered a form of rapid contextualization of the work for the reader, indicating, for example, which was the athletic victory that occasioned this epinician, which was the community who commissioned and performed this paean and at what religious venue, and so on, compensating for what would have been self-evident to an audience assisting at the first performance: 'by inscribing originally nonwritten, non-textual elements in written form they seal the textualization that these compositions had undergone.' However, the poem-titles of dithyrambs, such as Bacchylides' poems 15 (Antenoridae) and 17 (Eïtheoi), may actually go back to the fifth-century poets themselves, and would thus relate to "Stage 1 ". Poem-titles play a key role in the reception of lyric: they not only provide evidence for how poems were viewed in (Hellenistic) antiquity, but also exercise a decisive and long-lasting influence on the way the poems come to be viewed in their subsequent reception, once the title has become an inalienable part of the text's tradition, from antiquity to the present. Titles of whole books of lyric poetry (Epinicians, Paeans, etc.) have a key role in the conceptualization of the miscellaneous sub-genres of Greek lyric. Individual poem-titles interact crucially with book-titles by 'simultaneously individualiz[ing] each poem through the specific indications that they offer, and contribut [ing] to characterizing the genre through the elements that they consistently put forward for that purpose. ${ }^{97}$ Poem-titles may not only conform to and confirm the characteristics of the genre declared in the book-title; they may also offer complications, such as the hybridizing title that declares Pindar Paean $\mathrm{D}_{7}$ Rutherford 'a prosodiac paean', or even negations of them: thus an oschophorikon (Pindar fr. 6c, from the book of 'Isthmians') is evidently not properly an Isthmian ode nor an epinician. The other major issue in Prodi's chapter is whether poem-titles have merely exegetical value (in the event that they represent just a scholarly inference

97 Prodi, this volume, p. 487. 
from the text) or whether they may have independent evidentiary value (in the event that they preserve independently known information). Prodi considers the likelihood of whether the poem-titles of Pindar's epinicians are informed by the Olympic and Pythian victor lists compiled by Hippias and Callisthenes respectively, and whether the dithyrambs can be seen as taking their titles from Athenian victor lists (didaskaliai) — if these lists both named dithyrambic poets and recorded their poem-titles.

The reception, and transmission, of Greek lyric poetry in the Roman imperial period, specifically the third century $\mathrm{CE}$, is the subject of Johannes Breuer's Ita dictum accipe: Pomponius Porphyrio on Early Greek Lyric Poetry in Horace. Breuer points out that the treatment of the Greek lyric poets by the third-century Horatian commentator Porphyrio is superficial. He will typically identify the poets referred to antonomastically by Horace; thus Lesboum ... barbiton (Horace, Odes 1.1) is explained as a reference to Sappho and Alcaeus, as is 'common knowledge' (manifestum). In general, he references the poets' biographical traditions rather than their actual poems. Thus, commenting on Odes 1.14 and 1.32, Porphyrio points to Alcaeus' opposition to Mytilenean tyrants, but does not reference any Alcaean poem about shipwreck or the allegorical interpretation of the Alcaean storm-tossed ship. ${ }^{98}$ In commenting on Odes 2.13, Porphyrio concentrates on providing "biographical" information about Sappho and Alcaeus. Thus Sappho as querentem / ... puellis de popularibus is explained with reference to the biographical tradition about her love for Phaon. Alcaeus as plenius sonantem is explained with reference to the image of Alcaeus as embroiled in wars, in seafaring, and in bouts of exile at the hands of tyrants (an image developed by Horace himself in Odes 1.32), these being the 'fuller strain' of Alcaeus' song. In commenting on Horace Epistles 1.19, Porphyrio cites the biographical tradition of Sappho's love for women and the story concerning Archilochus, Lycambes, and Neobule. In explaining Alcaeus' 'threatening' Muses of Odes 4.9.7, Porphyrio instances Alcaeus' role in the expulsion of tyrants (alluded to by Horace at Odes 2.13.31). Porphyrio does indicate some of Horace's poetic debts to the lyric poets when these are not explicitly named by Horace (Alcaeus in Odes 1.10, Pindar in 1.12, Bacchylides in 1.15, Anacreon in 1.27); however, we are aware of many more obvious Greek lyric intertexts for Horace than Porphyrio acknowledges. Porphyrio's awareness of Greek lyric thus appears to be both attenuated and, often, mediated by the biographical tradition. Breuer introduces a telling control: Porphyrio is both interested and

98 On the allegorical interpretation of the Alcaean storm-tossed ship, see Bowie's contribution to this volume, pp. 287-293. 
able to quote many Latin intertexts for Horace, and able also to put them to more constructive use, as linguistic, motival, or thematic parallels for Horace: the implication is that he would have done the same with the Greek lyric poets, had he been able to do so. A plausible argument from silence thus indicates that Prophyrio, and perhaps his peers in the third century CE, were barely conversant with early Greek lyric.

The ancient tradition of Pindaric scholarship, whose Hellenistic phase was examined by Phillips, lasted until the Byzantine period, and the last known commentary is by Eustathius of Thessalonica (twelfth century), which like its Hellenistic predecessors, is lost, apart from its introduction. Arlette NeumannHartmann, in 'Pindar and his Commentator Eustathius of Thessalonica', illuminates this commentary as far as possible, drawing not only, as other scholars have done, on its extant introduction, but also from the many (approximately 220) scattered references to Pindar in Eustathius' other surviving commentaries on poetic works-Homer's Iliad and Odyssey, and Dionysius Periegetes' Description of the Known World - which were evidently written after his work on Pindar (they refer to it eight times). It emerges that Eustathius' knowledge of Pindar seems to have been largely confined to the Epinicia (though, unlike us, he knew the complete book of Isthmians), and his knowledge of poems from other genres may have been owed to the indirect tradition, perhaps as this had already been incorporated into the Pindaric commentary tradition. Unlike the ancient Pindar scholia, Eustathius' commentary covered only a selection of Pindar's epinicians, ranging over all four books of the Epinicia. Poems certainly included were Olympian 10, Pythians 1, 2, 4, 12, Nemean 2, and Isthmian 5. The commentary was heavily dependent on the ancient Pindar scholia, but also included significant new material and insights. Thus it is possible to say that Eustathius had an interest in Pindar's Doric dialect (one note dealt with the use of $\dot{\varepsilon} \nu$ with the accusative), Pindar's diction (for instance, his fondness for the verb $\mu$ ir $v u \mu$, in non-literal senses), and Pindar's mytho$\operatorname{logy}$ (the Sphinx/Medusa, Heracles, and the Moliones, Zeus Ammon, the name Typhaon, the Centaur, and Nephele). Perhaps unsurprisingly, the commentaries on Homer reveal that Eustathius also must have taken a keen interest in epithets in Pindar (such as ह̇рı of Apollo). While much of course remains in the dark, Neumann-Hartmann thus manages to shed meaningful light on the Pindaric commentary tradition at the end of antiquity. 


\section{References}

Agócs, P., Carey, C., and Rawles, R., eds. 2012. Receiving the Komos: Ancient and Modern Receptions of the Victory Ode. London.

Acosta-Hughes, B. 2010. Arion's Lyre: Archaic Lyric into Hellenistic Poetry. Princeton.

Assmann, J. 2006. Religion and Cultural Memory: Ten Studies. Stanford.

Bagordo, A. 2003. Reminiszenzen früher Lyrik bei den attischen Tragikern: Beiträge zur Anspielungstechnik und poetischen Tradition. Zetemata 118. Munich.

Bakker, E. 2017. Trust and Fame: The Seal of Theognis. In Authorship and Greek Song Authority, Authenticity, and Performance. Studies in Archaic and Classical Greek Song 3, ed. E. Bakker, 99-121. Leiden.

Barbantani, S. 1993. I poeti lirici del canone alessandrino nell'epigrammistica. Aevum(ant) 6: 5-97.

Barbantani, S. 2009. Lyric in the Hellenistic Period and Beyond. In Budelmann 20o9: 297-318.

Barbantani, S. 2010. Three Burials (Ibycus, Stesichorus, Simonides): Facts and Fiction about Lyric Poets in Magna Graecia in the Epigrams of the 'Greek Anthology'. Alexandria.

Barchiesi, A. 20o9. Lyric in Rome. In Budelmann 2009: 319-335.

Baumbach, M. and Dümmler, N. 2014. Imitate Anacreon!: Mimesis, Poiesis and the Poetic Inspiration in the Carmina Anacreontea. Berlin.

Bernsdorff, H. 2014. Anacreon's Palinode. In Baumbach and Dümmler 2014:11-24.

Bing, P. 2014. Anacreontea avant la letter: Euripides, Cyclops 495-518. In Baumbach and Dümmler 2014: 25-46.

Bitto, G. 2012. Lyrik als Philologie. Zur Rezeption hellenistischer Pindarkommentierung in den Oden des Horaz. Rahden.

Bowie, E.L. 1989. Greek Sophists and Greek Poetry in the Second Sophistic. ANRW II 33.1: $209-258$.

Bowie, E.L. 1997. The Theognidea: A Step towards a Collection of Fragments? In Collecting Fragments. Fragmente sammeln, ed. G.W. Most, 53-66. Göttingen.

Bowie, E.L. 2008. Aristides and Early Greek Lyric, Elegiac and Iambic Poetry. In Aelius Aristides between Greece, Roma, and the Gods, ed. W.V. Harris and B. Holmes, 9-29. Leiden.

Braswell, B.K. 2013. Didymos of Alexandria: Commentary on Pindar. Basle.

Budelmann, F. 20og. The Cambridge Companion to Greek Lyric. Cambridge.

Calame, C. 1974. Réflexions sur les genres littéraires en Grèce antique. QUCC 17: 113128.

Campbell, D. 1984. Stobaeus and Early Greek Lyric Poetry. In Greek Poetry and Philosophy: Studies in Honor of Leonard Woodbury, ed. D.E. Gerber, 51-57. Chico.

Cannatà Fera, M. 1992. Il Pindaro di Plutarco. Messina. 
Carey, C. 2011. Alcman: From Laconia to Alexandria. In Archaic and Classical Choral Song: Performance, Politics and Dissemination. Trends in Classics-supplementary volumes, 10, ed. L. Athanassaki and E. Bowie, 437-46o. Berlin.

Cassio, A.C. 1997. Futuri dorici, dialetto di Siracusa e testo antico dei lirici greci. AION(filol) 19:187-214.

Cerri, G. 1991. Il significato di sphregis in Teognide e la salvaguardia dell'autenticità testuale nel mondo antico. $Q S$ 17/33: 21-40.

Chaniotis, A. 1988. Als die Diplomaten noch tanzten und sangen. Zu zwei Dekreten kretischer Städte in Mylasa. ZPE 71: 157.

Clay, D. 2004. Archilochos heros: The Cult of Poets in the Greek Polis. Washington, DC.

Colesanti, G. 2011. Questioni Teognidee. La genesi simposiale di un corpus di elegie. Rome.

Currie, B.G.F. 2017. Festival, Symposium, and Epinician (Re)performance: The Case of Nemean 4 and Others. In Hunter and Uhlig 2017: 187-208.

D’Alessio, G.B. 2017. Performance, Transmission, and the Loss of Hellenistic Lyric Poetry. In Hunter and Uhlig 2017: 232-261.

D’Alfonso, F. 200o. Anassimene e Ibico alla corte di Policrate (Metiochos et Parthenope; 'Unsurî, Vâmiq u 'Adhrâ). Helikon 35-38 (1995-1998): 55-76.

Degani, E. 1984. Studi su Ipponatte. Bari.

Degani, H. 1991. Hipponax: Testimonia et Fragmenta. 2nd edn. Stuttgart.

Dickey, E. 2007. Ancient Greek Scholarship. Oxford.

Dickey, E. 2015. The Sources of our Knowledge of Ancient Scholarship. In Montanari, Matthaios, and Rengakos 2015: 1.459-514.

Dover, K.J. 1993. Aristophanes Frogs. Oxford.

Feeney, D. 1993. Horace and the Greek lyric poets. In Horace 200o: A Celebration: Essays for the Bimillennium, ed. N. Rudd, 41-63. London.

Ford, A. 1995. The Origins of Criticism. Literary Culture and Poetic Theory in Classical Greece. Princeton.

Fowler, R.L. 2004. The Homeric Question. In The Cambridge Companion to Homer, ed. R.L. Fowler, 220-232. Cambridge.

Gerber, D.E. 1999. Greek Iambic Poetry. Cambridge, MA.

Gronewald, M. and Daniel, R.W. 2004. Ein neuer Sappho-Papyrus. ZPE 146: 1-8.

Hadjimichael, T.A. 2019. The Emergence of the Lyric Canon. Oxford.

Hagel, S. 2010. Ancient Greek Music: A New Technical History. Cambridge.

Hägg, T. and Utas, B. 2003. The Virgin and her Lover: Fragments of an Ancient Greek Novel and a Persian Epic Poem = Brill Studies in Middle Eastern Literatures, Supplements to the Journal of Arabic Literature, vol. Xxx. Leiden.

Hardie, P. 2005. Nonnus' Typhon: The Musical Giant. In Roman and Greek Imperial Epic, ed. M. Paschalis, 117-130. Herakleion.

Harvey, A.E. 1955. The Classification of Greek Lyric Poetry. CQ 5: 157-175.

Hawkins, T. 2014. Iambic Poetics in the Roman Empire. Cambridge. 
Herington, J. 1985. Poetry into Drama: Early Tragedy and the Greek Poetic Tradition. Berkeley.

Hunter, R.L. and Rutherford, I.C., eds. 20o9. Wandering Poets in Ancient Greek Culture: Travel, Locality and Pan-Hellenism. Cambridge.

Hunter, R.L. and Uhlig, A., eds. 2017. Imagining Reperformance in Ancient Culture: Studies in the Traditions of Drama and Lyric. Cambridge.

Hutchinson, G.O. 2001. Greek Lyric Poetry: A Commentary on Selected Larger Pieces. Oxford.

Hutchinson, G.O. 2007. Horace and Archaic Greek Poetry. In The Cambridge Companion to Horace, ed. S.J. Harrison, 36-49. Cambridge.

Irigoin, J. 1994. Les éditions de textes. In La philologie grecque à l'époque hellénistique et Romaine, ed. F. Montanari, 39-82. Geneva.

Irmscher, J. 1981. Pindar in Byzanz. In Aischylos und Pindar. Studien zu Werk und Nachwirkung. Schriften zur Geschichte und Kultur der Antike 19, ed. E.G. Schmidt, 296-302. Berlin.

Jacob, C. 2013. The Web of Athenaeus. Cambridge, MA.

Käppel, L. 200o. Bakchylides und das System der chorlyrischen Gattungen im 5.Jh. v. Chr. In Bakchylides 100 Jahre nach seiner Wiederentdeckung. Zetemata 106, ed. A. Bagordo and B. Zimmermann, 11-27. Munich.

Kroehnert, O. 1897. Canonesne poetarum scriptorum artificum per antiquitatem fuerunt? Königsberg/Kaliningrad.

Kugelmeier, C. 1996. Reflexe früher und zeitgenössischer Lyrik in der alten attischen Komödie. Beiträge zur Altertumskunde 8o. Stuttgart.

Lane Fox, R. 200o. Theognis: An Alternative to Democracy. In Alternatives to Athens, ed. R. Brock and S. Hodkinson, 35-51. Oxford.

Larson, J. 2002. Corinna and the Daughters of Asopus. SyllClass 13: 47-62.

Massimilla, G. 2012. Callimachus and Early Greek Elegy. In Hellenistic Studies at a Crossroads: Exploring Texts, Contexts and Metatexts, ed. R.L. Hunter, A. Rengakos, and E. Sistakou, 3-12. Berlin.

Masson, O. 1962. Les fragments du poète Hipponax. Études et Commentaires 43. Paris.

Matthaios, S. 2015. Greek Scholarship in the Imperial Era and Late Antiquity. In Montanari, Matthaios, and Rengakos 2015: 184-296.

Montana, F. 2015. Hellenistic Scholarship. In Montanari, Matthaios, and Rengakos 2015: $60-183$.

Montanari, F., Matthaios, S., and Rengakos, A., eds. 2015. Brill's Companion to Ancient Greek Scholarship. Leiden.

Most, G.W. 1987. Alcman's Cosmogonic Fragment (Fr. 5 Page, 81 Calame). CQ 37: 1-19.

Most, G.W. 1994. Simonides' Ode to Scopas in Contexts. In Modern Critical Theory and Classical Literature, ed. I. de Jong and J.P. Sullivan, 127-152. Leiden.

Nagy, G. 199o. Greek Mythology and Poetics. Ithaca. 
Nagy, G. 1996. Homeric Questions. Austin.

Nicolai, R. 1992. La storiografia nell'educazione antica. Pisa.

Nicolai, R. 2006. Alle origini dei canoni letterari: da Omero al Museo di Alessandri, Scienze umanistiche 2: 43-62.

Nicolai, R. 2014. The Canon and its Boundaries. In Submerged Literature in Ancient Greek Culture: An Introduction, ed. G. Colesanti and M. Giordano, 33-45. Berlin.

Nünlist, R. 2015. Poetics and Literary Criticism. In Montanari, Matthaios, and Rengakos 2015: 706-755.

Olson, S.D. 2007. Broken Laughter: Select Fragments of Greek Comedy. Oxford.

Parker, H.N. 1993. Sappho Schoolmistress. TAPhA 123: 309-351.

Paschalis, M., ed. 2002. Horace and Greek Lyric Poetry. Rethymnon.

Pfeiffer, R. 1968. History of Classical Scholarship from the Beginnings to the End of the Hellenistic Age. Oxford.

Phillips, T. 2015. Pindar's Library: Performance, Poetry, and Material Texts. Oxford.

Pontani, F. 2001. Le cadaver adoré: Sappho à Byzance. Byzantion 71: 233-25o.

Pontani, F. 2015. Scholarship in the Byzantine Empire (529-1453). In Montanari, Matthaios, and Rengakos 2015: 297-455.

Pordomingo Pardo, F. 2013. Antologías de época helenística en papiro. Florence.

Prauscello, L. 20og. Wandering Poetry, 'Travelling' Music: Timotheus' Muse and Some Case-Studies of Shifting Cultural Identities. In Hunter and Rutherford 20o9: 168-194.

Rawles, R. 2018. Simonides on Tombs, and the 'Tomb of Simonides'. In Tombs of the Ancient Poets: Between Literary Reception and Material Culture, ed. N. Goldschmidt and B. Graziosi, 51-68. Oxford.

Rosenmeyer, P.A. 1992. The Poetics of Imitation: Anacreon and the Anacreontic Tradition . Cambridge.

Rosenmeyer, P.A. 2008. Greek Verse Inscriptions in Roman Egypt: Julia Balbilla's Sapphic Voice. ClAnt 27: 334-358.

Rossi, L.E. 1971. Generi letterari e le loro leggi scritte e non scritte nelle letterature classiche. BICS 18: 69-94.

Rotstein, A. 2007. Critias' Invective Against Archilochus. CPh 102: 139-154.

Rotstein, A. 2010. The Idea of Iambos. Oxford.

Rotstein, A. 2016. The Ancient Literary History of Iambos. In Iambus and Elegy: New Approaches, ed. L. Swift and C. Carey, 101-121. Oxford.

Russell, D.A. and Wilson, N.G., ed. 1981. Menander Rhetor. Oxford.

Rutherford, I.C. 2012. On the Impossibility of Centaurs: The Reception of Pindar in the Roman Empire. In Agócs, Carey, and Rawles 2012: 93-104.

Schlesier, R. 2013. Atthis, Gyrinno, and other hetairai: Female Personal Names in Sappho's Poetry. Philologus 157: 199-222.

Stehle, E. 1997. Performance and Gender in Ancient Greece: Nondramatic Poetry in its Setting. Princeton. 
Stehle, E. 2004. Choral Prayer in Greek Tragedy: Euphemia or Aischrologia? In Music and the Muses: The Culture of Mousike in the Classical Athenian City, ed. P. Murray and P. Wilson. 121-155. Oxford.

Stehle, E. 2006. Solon's Self-reflexive Political Persona and its Audience. In Solon of Athens: New Historical and Philological Approaches, ed. J.H. Blok and A.P.M.H. Lardinois, 79-113. Leiden.

Swift, L. 2010. The Hidden Chorus: Echoes of Genre in Tragic Lyric. Oxford.

Van Minnen, P. 1997. The Performance and Readership of the Persai of Timotheus. APF 34: 246-255.

Vassilaki, E. 2005. Réminiscences de Pindare dans l' “Hymne à Sarapis” d' Aelius Aristide (Or. XLV). Euphrosyne 33: 325-339.

West, M.L. 197o. Corinna. CQ 20: 277-287.

West, M.L. 1974. Studies in Greek Elegy and Iambus. Berlin.

West, M.L. 1978. Stesichorus at Lille. ZPE 29: 1-4.

West, M.L. (1984), Carmina Anacreontea (Leipzig).

Whitmarsh, T. 2004. The Cretan Lyre Paradox: Mesomedes, Hadrian and the Poetics of Patronage. In Paideia: The World of the Second Sophistic, ed. B. Borg, 377-402. Berlin. Wilamowitz-Moellendorff. U. von. 1921. Griechische Verskunst. Berlin.

Wilamowitz-Moellendorff. U. von 1900. Textgeschichte der griechischen Lyriker. Berlin. Wright, M.E. 2012. The Comedian as Critic: Greek Old Comedy and Poetics. London.

Yatromanolakis, D. 2007. Sappho in the Making: The Early Reception. Cambridge, MA. 